\title{
ErbB Receptors and ErbB Targeted Therapies in Endometrial Cancer
}

\author{
Georgios Androutsopoulos*, Georgios Michail, Georgios Adonakis, Georgios Decavalas \\ Department of Obstetrics and Gynecology, University of Patras Medical School, Rion, Greece \\ Email: ${ }^{*}$ androutsopoulosgeorgios@hotmail.com
}

Received 15 March 2014; revised 10 April 2014; accepted 17 April 2014

Copyright (C) 2014 by authors and Scientific Research Publishing Inc.

This work is licensed under the Creative Commons Attribution International License (CC BY).

http://creativecommons.org/licenses/by/4.0/

(c) (i) Open Access

\begin{abstract}
The Epidermal Growth Factor system is present in human organs and plays an important role in cell proliferation, differentiation and apoptosis during embryogenesis and postnatal development. It has four receptors (EGFR, ErbB-2, ErbB-3 and ErbB-4) and numerous ligands. Dysregulation of the Epidermal Growth Factor signaling network is implicated in the pathogenesis of various disorders. Especially in cancer, the Epidermal Growth Factor system becomes hyperactivated with various mechanisms (ligand overproduction, receptor overproduction, constitutive receptor activation). EGFR overexpression may have a dual role in endometrial cancer. It seems that in type I endometrial cancer, EGFR overexpression did not affect disease progression. However in type II endometrial cancer, EGFR overexpression associated with high grade disease and adverse clinical outcome. Moreover ErbB-2 overexpression especially in type II endometrial cancer, is an indicator of a highly aggressive disease with poor overall survival. The potential role of ErbB receptors (especially EGFR and ErbB-2) as targets for cancer therapy has been investigated for over 20 years. There are 2 major classes of ErbB targeted therapies: anti-ErbB monoclonal antibodies (MoAbs) and ErbB-specific tyrosine kinase inhibitors (TKIs). ErbB targeted therapies have still shown modest effect in unselected endometrial cancer patients. However, they may be clinically active as adjuvant therapy in well-defined subgroups of type II endometrial cancer patients with EGFR and ErbB-2 overexpression.
\end{abstract}

\section{Keywords}

Endometrial Cancer, ErbB Receptors, ErbB Targeted Therapy

\section{Introduction}

Endometrial cancer (EC) is the most common malignancy of the female genital tract and occurs primarily in

${ }^{*}$ Corresponding author. 
postmenopausal women [1] [2]. Overall, about 2.64\% of women develop EC during their lifetime [1].

The epidermal growth factor system (EGF system) is present in human organs and plays an important role in cell proliferation, differentiation and apoptosis during embryogenesis and postnatal development [3] [4].

Dysregulation of the EGF signaling network is implicated in various disorders [3] [5]. Especially in cancer, the EGF system contributes in proliferation, transformation, angiogenesis, migration and invasion [6].

\section{Epidermal Growth Factor System}

\subsection{Receptors and Ligands}

The EGF system is present in human organs and play important role during embryogenesis and postnatal development [3] [4]. It has 4 receptors: epidermal growth factor receptor (EGFR or ErbB-1), ErbB-2, ErbB-3 and ErbB-4 [3] [6] [7].

ErbB receptors belong to subclass I of the superfamily of Receptor Tyrosine Kinases (RTKs) [3] [6]. They are trans-membrane glycoproteins with an extracellular region containing two ligand-binding domains, an extracellular juxtamembrane region, a hydrophobic transmembrane domain and an intracellular domain with tyrosine kinase activity [7] [8]. ErbB receptors catalyze the transfer of the $\gamma$ phosphate of ATP to hydroxyl groups of tyrosines in target proteins [9].

Moreover, EGF system has numerous ligands. According to their affinity for one or more ErbB receptors, the ligands divided into:

1) Ligands with binding specificity for EGFR: EGF, transforming growth factor-a (TGF-a) and amphiregulin (AR) [6] [7] [10].

2) Ligands with dual binding specificity for EGFR and ErbB-4: betacellulin (BTC), heparin-binding growth factor (HB-EGF) and epiregulin (EPR) [6] [7] [10].

3) Ligands with binding specificity for ErbB-3 and ErbB-4: neuregulins (NRGs) or heregulins (HRGs). They divided in two subgroups based on their ability to bind ErbB-3 and ErbB-4 (NRG-1 and NRG-2) or only ErbB-4 (NRG-3 and NRG-4) [6] [7] [10]-[12].

The ligands for ErbB receptors bind to the extracellular domain, resulting in receptor activation by homodimer and/or heterodimer formation and the subsequent transphosphorylation of tyrosine residues in the cytoplasmic region [6] [7] [13]. However, there is no direct ligand for ErbB-2 receptor [6].

\subsection{Receptor Activation}

The extracellular region of EGFR, ErbB-3 and ErbB-4 has two distinct conformations: the closed conformation (inactive) and the open conformation (active) [8] [14] [15].

In the absence of ligand binding, the extracellular region of EGFR, ErbB-3 and ErbB-4 has equilibrium between closed and open conformation [8] [14]-[16]. This equilibrium favours the closed conformation [8] [16].

Ligand binding stabilizes extracellular region in the open conformation and leads to the formation of both homodimeric and heterodimeric ErbB receptor complexes [8] [15]-[17]. The dimeric formation triggers receptor activation by an allosteric mechanism [18]. That leads to intracellular kinase activation and initiation of downstream signaling pathways [7] [17] [19].

The extracellular region of ErbB-2 has a conformation not suitable for ligand binding [20]. However, ErbB-2 is capable for ligand independent dimerization and signaling [8] [20]. At elevated expression levels ErbB-2 homodimerizes [20]. Moreover, ErbB-2 heterodimerizes with other ErbB receptors and it is their preferred heterodimerization partner [7] [17] [20]-[22].

ErbB-3 lacks intrinsic tyrosine kinase activity [23]. It can initiate signaling only in association with another ErbB receptor, usually ErbB-2 [23].

The dimerization of ErbB receptors represents the fundamental mechanism that drives transformation [24]. Although both homodimerization and heterodimerization result in activation of the EGF signaling network, heterodimers are more potent and mitogenic [5].

\subsection{Intracellular Signaling}

Dimerization of ErbB receptors leads to intracellular kinase activation [7] [17] [19]. As a result, a number of tyrosine residues in the $\mathrm{COOH}$-terminal portion of ErbB receptors become phosphorylated [6] [20] [24]. These 
phosphorylated tyrosine residues function as docking sites for cytoplasmic proteins containing Src homology 2 (SH2) and phosphotyrosine binding (PTB) domains [5] [7] [24] [25]. Recruitment of proteins initiates intracellular signaling via several pathways:

1) Ras/Raf/mitogen-activated protein kinase (MAPK) pathway [26]-[30].

2) Phosphatidylinositol 3-kinase (PI3K)/Akt pathway [26] [31]-[34].

3) Signal transducers and activators of transcription (STAT) pathway [35]-[39].

4) Src Kinase pathway [40]-[43].

5) Phospholipase C $\gamma /$ protein kinase C pathway [44]-[47].

\subsection{Dysregulation and Oncogenesis}

Dysregulation of the EGF signaling network is implicated in cancer, diabetes, autoimmune, inflammatory, cardiovascular and nervous system disorders [3] [5].

Loss of control of the cell functions mediated by the EGF signaling network is a hallmark of oncogenesis, in which the balance between cell proliferation and differentiation is disturbed. Several types of human cancer associated with dysregulation of the EGF signaling network [3].

In cancer, the EGF signaling network becomes hyperactivated with various mechanisms (ligand overproduction, receptor overproduction, constitutive receptor activation) [5] [7] [48]. Moreover contributes in proliferation, transformation, angiogenesis, migration and invasion [6].

\section{Endometrial Cancer}

\subsection{Classification}

EC is the most common malignancy of the female genital tract [1]. Based on clinical and pathological features, sporadic EC is classified into 2 types [49] [50].

1) Type I EC, represents the majority of sporadic EC cases (70\% - 80\%) [49] [50]. It is usually well differentiated and endometrioid in histology [49]-[51]. It is estrogen-related, usually arises from endometrial hyperplasia, has less aggressive clinical course and favorable prognosis [49] [50] [52].

2) Type II EC, represents the minority of sporadic EC cases (10\% - 20\%) [49] [50]. It is poorly differentiated and usually papillary serous or clear cell in histology [49]-[51]. It is not estrogen-related, arises from atrophic endometrium, has aggressive clinical course and propensity for early spread and poor prognosis [49] [53] [54].

\subsection{Expression and Clinical Significance of ErbB Receptors}

Due to the inactive status of postmenopausal endometrium, it is expectable to find significantly higher expression of the ErbB receptors in EC tissue [55].

In endometrium, EGFR localized to the basal part of surface epithelial cells, only in stromal cells, or both to epithelial and stromal cells [56]-[65]. It is primarily located to the cell membrane but also located to the cytoplasm [55] [61]-[69].

In unselected patients with EC, it has been reported EGFR expression in 43\% - 67\% of cases [61]-[63] [67]-[72]. In patients with type I EC, it has been reported EGFR expression in $46 \%$ of cases [63]. In patients with type II EC, it has been reported EGFR expression in 34\% - 50\% of cases [63] [64] [71].

EGFR over expression may have a dual role in EC [71]. It seems that in type I EC, EGFR overexpression did not affect disease progression [71]. However in type II endometrial cancer, EGFR overexpression associated with high grade disease and adverse clinical outcome [63] [64] [71].

In endometrium, ErbB-2 localized baso-laterally in the glands and surface epithelial cells [56] [57] [60]-[65] [73]. It is located to the cell membrane [55] [61]-[65] [67] [68] [74].

In unselected patients with EC, ErbB-2 amplification/overexpression represents a rare event [72]. In patients with type I EC, it has been reported ErbB-2 receptor overexpression in 8\% of cases and ErbB-2 gene amplification in 1.4\% - 3\% of cases [71] [75]. Although ErbB-2 amplification/overexpression is more common in patients with type II EC, the exact frequency remains controversial [63] [64] [71]. However, there are racial differences regarding ErbB-2 overexpression in patients with type II EC [76]. ErbB-2 overexpression is more common in Black race patients with type II EC [65] [76]. 
In patients with papillary serous EC, it has been reported ErbB-2 receptor overexpression in $18 \%-80 \%$ of cases and ErbB-2 gene amplification in 17\% - 47\% of cases [63] [64] [71] [75] [77]-[79]. In patients with clear cell EC, it has been reported ErbB-2 receptor overexpression in 33\% of cases and ErbB-2 gene amplification in $16 \%-50 \%$ of cases [63] [64] [71] [75] [78]. ErbB-2 overexpression especially in type II EC, is an indicator of a highly aggressive disease with poor overall survival [63] [64] [74] [75] [77] [80] [81].

In endometrium, ErbB-3 localized to surface epithelial cells [60]-[65] [82] [83]. It is located to the cytoplasm, with membrane staining in a minority of samples [55] [61]-[65] [83].

The clinical significance of ErbB-3 has not been studied well in EC [55] [61]-[65] [83].

In endometrium, ErbB-4 localized to epithelial and stromal cells [60]-[65] [83] [84]. It is located to the cytoplasm, with membrane staining in a minority of samples [55] [61]-[65] [83].

The clinical significance of ErbB-4 has not been studied well in EC [55] [61]-[65] [83].

\section{ErbB Targeted Therapies}

\subsection{Classification}

EGFR and ErbB-2 as targets for cancer therapy have been investigated for over 30 years [85]. There are 2 major classes of ErbB targeted therapies: [85] [86].

\subsubsection{Anti-ErbB Monoclonal Antibodies (MoAbs)}

1) Anti-EGFR MoAbs (cetuximab, panitumumab) bind to the extracellular domain of EGFR and prevent ligand binding and ligand dependent receptor activation [85] [86].

2) Anti-ErbB-2 MoAb (trastuzumab) binds to the extracellular domain of ErbB-2 and interferes with ligand independent receptor activation [85] [86]. However, the exact mechanism of action remains controversial [85] [86].

3) Anti-ErbB MoAb (pertuzumab) prevents receptor heterodimerization [85] [86].

\subsubsection{ErbB-Specific Tyrosine Kinase Inhibitors (TKIs)}

1) EGFR TKIs (gefitinib, erlotinib) block the binding of ATP to the intracellular domain of EGFR and prevent tyrosine kinase activity and subsequent intracellular signaling [85] [86].

2) EGFR and ErbB-2 TKI (lapatinib) block the binding of ATP to the intracellular domain of EGFR and ErbB-2 and prevents tyrosine kinase activity and subsequent intracellular signaling [85] [86].

\subsection{Effectiveness in Unselected Endometrial Cancer Patients}

\subsubsection{Anti-ErbB Monoclonal Antibodies (MoAbs) in Endometrial Cancer}

Anti-ErbB-2 MoAb (trastuzumab) may be an attractive and viable therapeutic option in patients with advanced, recurrent and/or metastatic EC overexpressing ErbB-2 [87].

Clinical responses to trastuzumab as single agent or in combination with chemotherapy have been reported in several case reports [87]-[90].

However a phase II study of trastuzumab as single agent in unselected patients with advanced or recurrent EC overexpressing ErbB-2, failed to demonstrate significant activity [91].

Moreover a phase II study of carboplatin/paclitaxel with or without trastuzumab in patients with advanced or recurrent type II EC (papillary serous) overexpressing ErbB-2, is currently underway (NCT01367002) [92].

\subsubsection{ErbB-Specific Tyrosine Kinase Inhibitors (TKIs) in Endometrial Cancer}

ErbB-specific TKIs (gefitinib, erlotinib, lapatinib) may be another viable therapeutic option in patients with advanced, recurrent and/or metastatic EC overexpressing EGFR and ErbB-2 [65] [93]-[95].

However a phase II study of gefitinib as single agent in unselected patients with persistent or recurrent EC overexpressing EGFR, demonstrate $4.1 \%$ complete response rate and $16.6 \%$ progression free survival $\geq 6$ months [93].

Also a phase II study of erlotinib as single agent in unselected patients with metastatic or recurrent EC, demonstrate $12.5 \%$ partial response rate [94].

Moreover a phase II study of lapatinib as single agent in unselected patients with persistent or recurrent EC, 
demonstrate $3.3 \%$ partial response rate and $10 \%$ progression free survival $\geq 6$ months [95].

\subsection{Effectiveness in Well-Defined Subgroups of Endometrial Cancer Patients}

Recent years, molecular targeted therapies have still shown modest effect in unselected EC patients [96]. Overall response rate to these drugs is modest, unless they are associated with chemotherapy or radiotherapy [85].

ErbB targeted therapies have not clinically tested in type II EC [71]. Perhaps they may be clinically active as adjuvant therapy in well-defined subgroups of type II EC patients with EGFR and ErbB-2 overexpression [64] [65] [71] [87]-[89] [97]-[104].

\section{Conclusion}

The role of ErbB targeted therapies in EC should be further investigated in clinical trials to evaluate their therapeutic efficacy [63]-[65] [71] [74] [87] [90]-[92] [94] [100] [101]. Moreover additional studies into the molecular pathways of EC development and progression, will increase our knowledge and lead to the discovery of new generation molecules with higher therapeutic efficacy [63]-[65].

\section{Conflict of Interest}

We declare that we have no conflict of interest.

\section{References}

[1] Siegel, R., Naishadham, D. and Jemal, A. (2013) Cancer Statistics, 2013. Cancer Journal for Clinicians, 63, 11-30. http://dx.doi.org/10.3322/caac.21166

[2] Sorosky, J. (2012) Endometrial Cancer. Obstetrics \& Gynecology, 120, 383-397. http://dx.doi.org/10.1097/AOG.0b013e3182605bf1

[3] Uberall, I., Kolar, Z., Trojanec, R., Berkovcova, J. and Hajduch, M. (2008) The Status and Role of ErbB Receptors in Human Cancer. Experimental and Molecular Pathology, 84, 79-89. http://dx.doi.org/10.1016/j.yexmp.2007.12.002

[4] Casalini, P., Iorio, M., Galmozzi, E. and Menard, S. (2004) Role of HER Receptors Family in Development and Differentiation. Journal of Cellular Physiology, 200, 343-350. http://dx.doi.org/10.1002/jcp.20007

[5] Marmor, M., Skaria, K. and Yarden, Y. (2004) Signal Transduction and Oncogenesis by ErbB/HER Receptors. International Journal of Radiation Oncology*Biology*Physics, 58, 903-913. http://dx.doi.org/10.1016/j.jjrobp.2003.06.002

[6] Holbro, T., Civenni, G. and Hynes, N. (2003) The ErbB Receptors and Their Role in Cancer Progression. Experimental Cell Research, 284, 99-110. http://dx.doi.org/10.1016/S0014-4827(02)00099-X

[7] Yarden, Y. (2001) The EGFR Family and Its Ligands in Human Cancer Signalling Mechanisms and Therapeutic Opportunities. European Journal of Cancer, 37, S3-8. http://dx.doi.org/10.1016/S0959-8049(01)00230-1

[8] Riese, D., Gallo, R. and Settleman, J. (2007) Mutational Activation of ErbB Family Receptor Tyrosine Kinases: Insights into Mechanisms of Signal Transduction and Tumorigenesis. Bioessays, 29, 558-565.

http://dx.doi.org/10.1002/bies.20582

[9] Hunter, T. (1998) The Croonian Lecture 1997. The Phosphorylation of Proteins on Tyrosine: Its Role in Cell Growth and Disease. Philosophical Transactions of the Royal Society B, 353, 583-605. http://dx.doi.org/10.1098/rstb.1998.0228

[10] Normanno, N., Bianco, C., De Luca, A., Maiello, M. and Salomon, D. (2003) Target-Based Agents against ErbB Receptors and Their Ligands: A Novel Approach to Cancer Treatment. Endocrine-Related Cancer, 10, 1-21. http://dx.doi.org/10.1677/erc.0.0100001

[11] Zhang, D., Sliwkowski, M., Mark, M., Frantz, G., Akita, R., Sun, Y., et al. (1997) Neuregulin-3 (NRG3): A Novel Neural Tissue-Enriched Protein That Binds and Activates ErbB4. Proceedings of the National Academy of Sciences, 94, 9562-9567. http://dx.doi.org/10.1073/pnas.94.18.9562

[12] Harari, D., Tzahar, E., Romano, J., Shelly, M., Pierce, J., Andrews, G., et al. (1999) Neuregulin-4: A Novel Growth Factor That Acts through the ErbB-4 Receptor Tyrosine Kinase. Oncogene, 18, 2681-2689. http://dx.doi.org/10.1038/sj.onc.1202631

[13] Alroy, I. and Yarden, Y. (1997) The ErbB Signaling Network in Embryogenesis and Oncogenesis: Signal Diversification through Combinatorial Ligand-Receptor Interactions. FEBS Letters, 410, 83-86. http://dx.doi.org/10.1016/S0014-5793(97)00412-2 
[14] Ferguson, K., Berger, M., Mendrola, J., Cho, H., Leahy, D. and Lemmon, M. (2003) EGF Activates Its Receptor by Removing Interactions That Autoinhibit Ectodomain Dimerization. Molecular Cell, 11, 507-517. http://dx.doi.org/10.1016/S1097-2765(03)00047-9

[15] Dawson, J., Berger, M., Lin, C., Schlessinger, J., Lemmon, M. and Ferguson, K. (2005) Epidermal Growth Factor Receptor Dimerization and Activation Require Ligand-Induced Conformational Changes in the Dimer Interface. Molecular Cell Biology, 25, 7734-7742. http://dx.doi.org/10.1128/MCB.25.17.7734-7742.2005

[16] Ozcan, F., Klein, P., Lemmon, M., Lax, I. and Schlessinger, J. (2006) On the Nature of Low- and High-Affinity EGF Receptors on Living Cells. Proceedings of the National Academy of Sciences of the United States of America, 103, 5735-5740. http://dx.doi.org/10.1073/pnas.0601469103

[17] Olayioye, M., Neve, R., Lane, H. and Hynes, N. (2000) The ErbB Signaling Network: Receptor Heterodimerization in Development and Cancer. The EMBO Journal, 19, 3159-3167. http://dx.doi.org/10.1093/emboj/19.13.3159

[18] Zhang, X., Gureasko, J., Shen, K., Cole, P.A. and Kuriyan, J. (2006) An Allosteric Mechanism for Activation of the Kinase Domain of Epidermal Growth Factor Receptor. Cell, 125, 1137-1149. http://dx.doi.org/10.1016/j.cell.2006.05.013

[19] Qian, X., LeVea, C., Freeman, J., Dougall, W. and Greene, M. (1994) Heterodimerization of Epidermal Growth Factor Receptor and Wild-Type or Kinase-Deficient Neu: A Mechanism of Interreceptor Kinase Activation and Transphosphorylation. Proceedings of the National Academy of Sciences of the United States of America, 91, 1500-1504. http://dx.doi.org/10.1073/pnas.91.4.1500

[20] Garrett, T., McKern, N., Lou, M., Elleman, T., Adams, T., Lovrecz, G., et al. (2003) The Crystal Structure of a Truncated ErbB2 Ectodomain Reveals an Active Conformation, Poised to Interact with Other ErbB Receptors. Molecular Cell, 11, 495-505. http://dx.doi.org/10.1016/S1097-2765(03)00048-0

[21] Hynes, N. and Stern, D. (1994) The Biology of erbB-2/neu/HER-2 and Its Role in Cancer. Biochimica et Biophysica Acta, 1198, 165-184.

[22] Graus-Porta, D., Beerli, R., Daly, J. and Hynes, N. (1997) ErbB-2, the Preferred Heterodimerization Partner of All ErbB Receptors, Is a Mediator of Lateral Signaling. The EMBO Journal, 16, 1647-1655. http://dx.doi.org/10.1093/emboj/16.7.1647

[23] Mass, R. (2004) The HER Receptor Family: A Rich Target for Therapeutic Development. International Journal of Radiation Oncology*Biology*Physics, 58, 932-940. http://dx.doi.org/10.1016/j.ijrobp.2003.09.093

[24] Zhang, H., Berezov, A., Wang, Q., Zhang, G., Drebin, J., Murali, R., et al. (2007) ErbB Receptors: From Oncogenes to Targeted Cancer Therapies. Journal of Clinical Investigation, 117, 2051-2058. http://dx.doi.org/10.1172/JCI32278

[25] Songyang, Z., Shoelson, S., Chaudhuri, M., Gish, G., Pawson, T., Haser, W., et al. (1993) SH2 Domains Recognize Specific Phosphopeptide Sequences. Cell, 72, 767-778. http://dx.doi.org/10.1016/0092-8674(93)90404-E

[26] Scaltriti, M. and Baselga, J. (2006) The Epidermal Growth Factor Receptor Pathway: A Model for Targeted Therapy. Clinical Cancer Research, 12, 5268-5272. http://dx.doi.org/10.1158/1078-0432.CCR-05-1554

[27] Lowenstein, E., Daly, R., Batzer, A., Li, W., Margolis, B., Lammers, R., et al. (1992) The SH2 and SH3 DomainContaining Protein GRB2 Links Receptor Tyrosine Kinases to Ras Signaling. Cell, 70, 431-442. http://dx.doi.org/10.1016/0092-8674(92)90167-B

[28] Batzer, A., Rotin, D., Urena, J., Skolnik, E. and Schlessinger, J. (1994) Hierarchy of Binding Sites for Grb2 and Shc on the Epidermal Growth Factor Receptor. Molecular and Cellular Biology, 14, 5192-5201.

[29] Hill, C. and Treisman, R. (1995) Transcriptional Regulation by Extracellular Signals: Mechanisms and Specificity. Cell, 80, 199-211. http://dx.doi.org/10.1016/0092-8674(95)90403-4

[30] Gaestel, M. (2006) MAPKAP Kinases-MKs-Two’s Company, Three’s a Crowd. Nature Reviews, Molecular Cell Biology, 7, 120-130. http://dx.doi.org/10.1038/nrm1834

[31] Vivanco, I. and Sawyers, C. (2002) The Phosphatidylinositol 3-Kinase AKT Pathway in Human Cancer. Nature Reviews Cancer, 2, 489-501. http://dx.doi.org/10.1038/nrc839

[32] Yu, J., Wjasow, C. and Backer, J. (1998) Regulation of the p85/p110alpha Phosphatidylinositol 3'-Kinase. Distinct Roles for the n-Terminal and c-Terminal SH2 Domains. The Journal of Biological Chemistry, 273, 30199-30203. http://dx.doi.org/10.1074/jbc.273.46.30199

[33] Mattoon, D., Lamothe, B., Lax, I. and Schlessinger, J. (2004) The Docking Protein Gab1 Is the Primary Mediator of EGF-Stimulated Activation of the PI-3K/Akt Cell Survival Pathway. BMC Biology, 2, 24. http://dx.doi.org/10.1186/1741-7007-2-24

[34] Carpenter, C., Auger, K., Chanudhuri, M., Yoakim, M., Schaffhausen, B., Shoelson, S., et al. (1993) Phosphoinositide 3-Kinase Is Activated by Phosphopeptides That Bind to the SH2 Domains of the 85-kDa Subunit. The Journal of Biological Chemistry, 268, 9478-9483. 
[35] Bromberg, J. (2002) Stat Proteins and Oncogenesis. Journal of Clinical Investigation, 109, 1139-1142. http://dx.doi.org/10.1172/JCI0215617

[36] Haura, E., Turkson, J. and Jove, R. (2005) Mechanisms of Disease: Insights into the Emerging Role of Signal Transducers and Activators of Transcription in Cancer. Nature Clinical Practice Oncology, 2, 315-324. http://dx.doi.org/10.1038/ncponc0195

[37] Zhong, Z., Wen, Z. and Darnell Jr., J. (1994) Stat3: A STAT Family Member Activated by Tyrosine Phosphorylation in Response to Epidermal Growth Factor and Interleukin-6. Science, 264, 95-98. http://dx.doi.org/10.1126/science.8140422

[38] Kloth, M., Laughlin, K., Biscardi, J., Boerner, J., Parsons, S. and Silva, C. (2003) STAT5b, a Mediator of Synergism between c-Src and the Epidermal Growth Factor Receptor. The Journal of Biological Chemistry, 278, 1671-1679. http://dx.doi.org/10.1074/jbc.M207289200

[39] Andl, C., Mizushima, T., Oyama, K., Bowser, M., Nakagawa, H. and Rustgi, A. (2004) EGFR-Induced Cell Migration Is Mediated Predominantly by the JAK-STAT Pathway in Primary Esophageal Keratinocytes. American Journal of Physiology-Gastrointestinal and Liver Physiology, 287, G1227-G1237. http://dx.doi.org/10.1152/ajpgi.00253.2004

[40] Yeatman, T. (2004) A Renaissance for SRC. Nature Reviews-Cancer, 4, 470-480. http://dx.doi.org/10.1038/nrc1366

[41] Summy, J. and Gallick, G. (2006) Treatment for Advanced Tumors: SRC Reclaims Center Stage. Clinical Cancer Research, 12, 1398-1401. http://dx.doi.org/10.1158/1078-0432.CCR-05-2692

[42] Jorissen, R., Walker, F., Pouliot, N., Garrett, T., Ward, C. and Burgess, A. (2003) Epidermal Growth Factor Receptor: Mechanisms of Activation and Signalling. Experimental Cell Research, 284, 31-53. http://dx.doi.org/10.1016/S0014-4827(02)00098-8

[43] Leu, T. and Maa, M. (2003) Functional Implication of the Interaction between EGF Receptor and c-Src. Frontiers in Bioscience, 8, s28-s38. http://dx.doi.org/10.2741/980

[44] Chattopadhyay, A., Vecchi, M., Ji, Q., Mernaugh, R. and Carpenter, G. (1999) The Role of Individual SH2 Domains in Mediating Association of Phospholipase C-Gamma1 with the Activated EGF Receptor. The Journal of Biological Chemistry, 274, 26091-26097. http://dx.doi.org/10.1074/jbc.274.37.26091

[45] Patterson, R., van Rossum, D., Nikolaidis, N., Gill, D. and Snyder, S. (2005) Phospholipase C-Gamma: Diverse Roles in Receptor-Mediated Calcium Signaling. Trends in Biochemical Sciences, 30, 688-697. http://dx.doi.org/10.1016/j.tibs.2005.10.005

[46] Schonwasser, D., Marais, R., Marshall, C. and Parker, P. (1998) Activation of the Mitogen-Activated Protein Kinase/ Extracellular Signal-Regulated Kinase Pathway by Conventional, Novel, and Atypical Protein Kinase C Isotypes. Molecular and Cellular Biology, 18, 790-798.

[47] McClellan, M., Kievit, P., Auersperg, N. and Rodland, K. (1999) Regulation of Proliferation and Apoptosis by Epidermal Growth Factor and Protein Kinase C in Human Ovarian Surface Epithelial Cells. Experimental Cell Research, 246, 471-479. http://dx.doi.org/10.1006/excr.1998.4328

[48] Salomon, D., Brandt, R., Ciardiello, F. and Normanno, N. (1995) Epidermal Growth Factor-Related Peptides and Their Receptors in Human Malignancies. Critical Reviews in Oncology/Hematology, 19, 183-232. http://dx.doi.org/10.1016/1040-8428(94)00144-I

[49] Bokhman, J. (1983) Two Pathogenetic Types of Endometrial Carcinoma. Gynecologic Oncology, 15, 10-17. http://dx.doi.org/10.1016/0090-8258(83)90111-7

[50] Doll, A., Abal, M., Rigau, M., Monge, M., Gonzalez, M., Demajo, S., et al. (2008) Novel Molecular Profiles of Endometrial Cancer-New Light through Old Windows. The Journal of Steroid Biochemistry and Molecular Biology, 108, 221-229. http://dx.doi.org/10.1016/j.jsbmb.2007.09.020

[51] Lax, S. (2004) Molecular Genetic Pathways in Various Types of Endometrial Carcinoma: From a Phenotypical to a Molecular-Based Classification. Virchows Archiv, 444, 213-223. http://dx.doi.org/10.1007/s00428-003-0947-3

[52] Sherman, M., Sturgeon, S., Brinton, L., Potischman, N., Kurman, R., Berman, M., et al. (1997) Risk Factors and Hormone Levels in Patients with Serous and Endometrioid Uterine Carcinomas. Modern Pathology, 10, 963-968.

[53] Abeler, V. and Kjorstad, K. (1991) Clear Cell Carcinoma of the Endometrium: A Histopathological and Clinical Study of 97 Cases. Gynecologic Oncology 40, 207-217. http://dx.doi.org/10.1016/0090-8258(90)90279-T

[54] Goff, B., Kato, D., Schmidt, R., Ek, M., Ferry, J., Muntz, H., et al. (1994) Uterine Papillary Serous Carcinoma: Patterns of Metastatic Spread. Gynecologic Oncology, 54, 264-268. http://dx.doi.org/10.1006/gyno.1994.1208

[55] Ejskjaer, K., Sorensen, B.S., Poulsen, S.S., Forman, A., Nexo, E. and Mogensen, O. (2007) Expression of the Epidermal Growth Factor System in Endometrioid Endometrial Cancer. Gynecologic Oncology, 104, 158-167. http://dx.doi.org/10.1016/j.ygyno.2006.07.015

[56] Bigsby, R., Li, A., Bomalaski, J., Stehman, F., Look, K. and Sutton, G. (1992) Immunohistochemical Study of 
HER-2/neu, Epidermal Growth Factor Receptor, and Steroid Receptor Expression in Normal and Malignant Endometrium. Obstetrics \& Gynecology, 79, 95-100.

[57] Wang, X., Das, S., Damm, D., Klagsbrun, M., Abraham, J. and Dey, S. (1994) Differential Regulation of HeparinBinding Epidermal Growth Factor-Like Growth Factor in the Adult Ovariectomized Mouse Uterus by Progesterone and Estrogen. Endocrinology, 135, 1264-1271. http://dx.doi.org/10.1210/en.135.3.1264

[58] Imai, T., Kurachi, H., Adachi, K., Adachi, H., Yoshimoto, Y., Homma, H., et al. (1995) Changes in Epidermal Growth Factor Receptor and the Levels of Its Ligands during Menstrual Cycle in Human Endometrium. Biology of Reproduction, 52, 928-938. http://dx.doi.org/10.1095/biolreprod52.4.928

[59] Moller, B., Rasmussen, C., Lindblom, B. and Olovsson, M. (2001) Expression of the Angiogenic Growth Factors VEGF, FGF-2, EGF and Their Receptors in Normal Human Endometrium during the Menstrual Cycle. Molecular Human Reproduction, 7, 65-72. http://dx.doi.org/10.1093/molehr/7.1.65

[60] Ejskjaer, K., Sorensen, B.S., Poulsen, S.S., Mogensen, O., Forman, A. and Nexo, E. (2005) Expression of the Epidermal Growth Factor System in Human Endometrium during the Menstrual Cycle. Molecular Human Reproduction, 11, 543-551. http://dx.doi.org/10.1093/molehr/gah207

[61] Androutsopoulos, G., Adonakis, G., Gkermpesi, M., Gkogkos, P., Ravazoula, P. and Kourounis, G. (2006) Expression of the Epidermal Growth Factor System in Endometrial Cancer after Adjuvant Tamoxifen Treatment for Breast Cancer. European Journal of Gynaecological Oncology, 27, 490-494.

[62] Adonakis, G., Androutsopoulos, G., Koumoundourou, D., Liava, A., Ravazoula, P. and Kourounis, G. (2008) Expression of the Epidermal Growth Factor System in Endometrial Cancer. European Journal of Gynaecological Oncology, 29, 450-454.

[63] Adonakis, G. and Androutsopoulos, G. (2012) The Role of ErbB Receptors in Endometrial Cancer. In: Saldivar, J.S., Ed., Cancer of the Uterine Endometrium-Advances and Controversies, InTech, 23-38.

[64] Androutsopoulos, G., Adonakis, G., Liava, A., Ravazoula, P. and Decavalas, G. (2013) Expression and Potential Role of ErbB Receptors in Type II Endometrial Cancer. European Journal of Obstetrics \& Gynecology and Reproductive Biology, 168, 204-208. http://dx.doi.org/10.1016/j.ejogrb.2013.01.007

[65] Androutsopoulos, G., Adonakis, G. and Decavalas, G. (2014) ErbB Targeted Therapy in Endometrial Cancer. In: Farghaly, S., Ed., Endometrial Cancer: Current Incidence, Diagnosis and Management, Nova Science Publishers, Hauppauge, in press.

[66] Nyholm, H., Nielsen, A. and Ottesen, B. (1993) Expression of Epidermal Growth Factor Receptors in Human Endometrial Carcinoma. The International Journal of Gynecological Pathology, 12, 241-245. http://dx.doi.org/10.1097/00004347-199307000-00007

[67] Reinartz, J., George, E., Lindgren, B. and Niehans, G. (1994) Expression of p53, Transforming Growth Factor Alpha, Epidermal Growth Factor Receptor, and c-erbB-2 in Endometrial Carcinoma and Correlation with Survival and Known Predictors of Survival. Human Pathology, 25, 1075-1083. http://dx.doi.org/10.1016/0046-8177(94)90068-X

[68] Khalifa, M.A., Mannel, R.S., Haraway, S.D., Walker, J. and Min, K.W. (1994) Expression of EGFR, HER-2/neu, P53, and PCNA in Endometrioid, Serous Papillary, and Clear Cell Endometrial Adenocarcinomas. Gynecologic Oncology, 53, 84-92. http://dx.doi.org/10.1006/gyno.1994.1092

[69] Niikura, H., Sasano, H., Kaga, K., Sato, S. and Yajima, A. (1996) Expression of Epidermal Growth Factor Family Proteins and Epidermal Growth Factor Receptor in Human Endometrium. Human Pathology, 27, 282-289. http://dx.doi.org/10.1016/S0046-8177(96)90070-2

[70] Scambia, G., Benedetti Panici, P., Ferrandina, G., Battaglia, F., Distefano, M., D’Andrea, G., et al. (1994) Significance of Epidermal Growth Factor Receptor Expression in Primary Human Endometrial Cancer. International Journal of Cancer, 56, 26-30. http://dx.doi.org/10.1002/ijc.2910560106

[71] Konecny, G., Santos, L., Winterhoff, B., Hatmal, M., Keeney, G.L., Mariani, A., et al. (2009) HER2 Gene Amplification and EGFR Expression in a Large Cohort of Surgically Staged Patients with Nonendometrioid (type II) Endometrial Cancer. British Journal of Cancer, 100, 89-95. http://dx.doi.org/10.1038/sj.bjc.6604814

[72] Brys, M., Semczuk, A., Rechberger, T. and Krajewska, W. (2007) Expression of erbB-1 and erbB-2 Genes in Normal and Pathological Human Endometrium. Oncology Reports, 18, 261-265.

[73] Miturski, R., Semczuk, A. and Jakowicki, J. (1998) C-erbB-2 Expression in Human Proliferative and Hyperplastic Endometrium. International Journal of Gynecology \& Obstetrics, 61, 73-74. http://dx.doi.org/10.1016/S0020-7292(98)00008-3

[74] Odicino, F., Bignotti, E., Rossi, E., Pasinetti, B., Tassi, R., Donzelli, C., et al. (2008) HER-2/neu Overexpression and Amplification in Uterine Serous Papillary Carcinoma: Comparative Analysis of Immunohistochemistry, Real-Time Reverse Transcription-Polymerase Chain Reaction, and Fluorescence in Situ Hybridization. International Journal of Gynecological Cancer, 18, 14-21. http://dx.doi.org/10.1111/j.1525-1438.2007.00946.x 
[75] Morrison, C., Zanagnolo, V., Ramirez, N., Cohn, D., Kelbick, N., Copeland, L., et al. (2006) HER-2 Is an Independent Prognostic Factor in Endometrial Cancer: Association with Outcome in a Large Cohort of Surgically Staged Patients. Journal of Clinical Oncology, 24, 2376-2385. http://dx.doi.org/10.1200/JCO.2005.03.4827

[76] Santin, A., Bellone, S., Siegel, E., Palmieri, M., Thomas, M., Cannon, M., et al. (2005) Racial Differences in the Overexpression of Epidermal Growth Factor Type II Receptor (HER2/neu): A Major Prognostic Indicator in Uterine Serous Papillary Cancer. American Journal of Obstetrics \& Gynecology, 192, 813-818. http://dx.doi.org/10.1016/j.ajog.2004.10.605

[77] Santin, A., Bellone, S., Van Stedum, S., Bushen, W., Palmieri, M., Siegel, E., et al. (2005) Amplification of c-erbB2 Oncogene: A Major Prognostic Indicator in Uterine Serous Papillary Carcinoma. Cancer, 104, 1391-1397. http://dx.doi.org/10.1002/cncr.21308

[78] Grushko, T., Filiaci, V., Mundt, A., Ridderstrale, K., Olopade, O. and Fleming, G. (2008) An Exploratory Analysis of HER-2 Amplification and Overexpression in Advanced Endometrial Carcinoma: A Gynecologic Oncology Group Study. Gynecologic Oncology, 108, 3-9. http://dx.doi.org/10.1016/j.ygyno.2007.09.007

[79] Slomovitz, B., Broaddus, R., Burke, T., Sneige, N., Soliman, P., Wu, W., et al. (2004) Her-2/neu Overexpression and Amplification in Uterine Papillary Serous Carcinoma. Journal of Clinical Oncology, 22, 3126-3132. http://dx.doi.org/10.1200/JCO.2004.11.154

[80] Lukes, A., Kohler, M., Pieper, C., Kerns, B., Bentley, R., Rodriguez, G., et al. (1994) Multivariable Analysis of DNA Ploidy, p53, and HER-2/neu as Prognostic Factors in Endometrial Cancer. Cancer, 73, 2380-2385. http://dx.doi.org/10.1002/1097-0142(19940501)73:9<2380::AID-CNCR2820730922>3.0.CO;2-G

[81] Togami, S., Sasajima, Y., Oi, T., Ishikawa, M., Onda, T., Ikeda, S., et al. (2012) Clinicopathological and Prognostic Impact of Human Epidermal Growth Factor Receptor Type 2 (HER2) and Hormone Receptor Expression in Uterine Papillary Serous Carcinoma. Cancer Science, 103, 926-932. http://dx.doi.org/10.1111/j.1349-7006.2012.02240.x

[82] Prigent, S., Lemoine, N., Hughes, C., Plowman, G., Selden, C. and Gullick, W. (1992) Expression of the c-erbB-3 Protein in Normal Human Adult and Fetal Tissues. Oncogene, 7, 1273-1278.

[83] Srinivasan, R., Benton, E., McCormick, F., Thomas, H. and Gullick, W. (1999) Expression of the c-erbB-3/HER-3 and c-erbB-4/HER-4 Growth Factor Receptors and Their Ligands, Neuregulin-1 Alpha, Neuregulin-1 Beta, and Betacellulin, in Normal Endometrium and Endometrial Cancer. Clinical Cancer Research, 5, 2877-2883.

[84] Chobotova, K., Karpovich, N., Carver, J., Manek, S., Gullick, W., Barlow, D., et al. (2005) Heparin-Binding Epidermal Growth Factor and Its Receptors Mediate Decidualization and Potentiate Survival of Human Endometrial Stromal Cells. The Journal of Clinical Endocrinology and Metabolism, 90, 913-919. http://dx.doi.org/10.1210/jc.2004-0476

[85] Baselga, J. and Arteaga, C.L. (2005) Critical Update and Emerging Trends in Epidermal Growth Factor Receptor Targeting in Cancer. Journal of Clinical Oncology, 23, 2445-2459. http://dx.doi.org/10.1200/JCO.2005.11.890

[86] Lurje, G. and Lenz, H.J. (2009) EGFR Signaling and Drug Discovery. Oncology, 77, 400-410. http://dx.doi.org/10.1159/000279388

[87] Santin, A., Bellone, S., Roman, J., McKenney, J. and Pecorelli, S. (2008) Trastuzumab Treatment in Patients with Advanced or Recurrent Endometrial Carcinoma Overexpressing HER2/neu. International Journal of Gynecology \& Obstetrics, 102, 128-131. http://dx.doi.org/10.1016/j.ijgo.2008.04.008

[88] Jewell, E., Secord, A., Brotherton, T. and Berchuck, A. (2006) Use of Trastuzumab in the Treatment of Metastatic Endometrial Cancer. International Journal of Gynecological Cancer, 16, 1370-1373. http://dx.doi.org/10.1111/j.1525-1438.2006.00543.x

[89] Villella, J., Cohen, S., Smith, D., Hibshoosh, H. and Hershman, D. (2006) HER-2/neu Overexpression in Uterine Papillary Serous Cancers and Its Possible Therapeutic Implications. International Journal of Gynecological Cancer, 16, 1897-1902. http://dx.doi.org/10.1111/j.1525-1438.2006.00664.x

[90] Santin, A. (2010) Letter to the Editor Referring to the Manuscript Entitled: "Phase II Trial of Trastuzumab in Women with Advanced or Recurrent HER-Positive Endometrial Carcinoma: A Gynecologic Oncology Group Study” Recently Reported by Fleming et al., (Gynecol Oncol., 116;15-20;2010). Gynecologic Oncology, 118, 95-96. http://dx.doi.org/10.1016/j.ygyno.2010.01.043

[91] Fleming, G., Sill, M., Darcy, K., McMeekin, D., Thigpen, J., Adler, L., et al. (2010) Phase II Trial of Trastuzumab in Women with Advanced or Recurrent, HER2-Positive Endometrial Carcinoma: A Gynecologic Oncology Group Study. Gynecologic Oncology, 116, 15-20. http://dx.doi.org/10.1016/j.ygyno.2009.09.025

[92] Roque, D. and Santin, A. (2013) Updates in Therapy for Uterine Serous Carcinoma. Current Opinion in Obstetrics and Gynecology, 25, 29-37. http://dx.doi.org/10.1097/GCO.0b013e32835af98d

[93] Leslie, K., Sill, M., Fischer, E., Darcy, K., Mannel, R., Tewari, K., et al. (2013) A Phase II Evaluation of Gefitinib in the Treatment of Persistent or Recurrent Endometrial Cancer: A Gynecologic Oncology Group study. Gynecologic Oncology, 129, 486-494. http://dx.doi.org/10.1016/j.ygyno.2013.02.019 
[94] Oza, A., Eisenhauer, E., Elit, L., Cutz, J., Sakurada, A., Tsao, M., et al. (2008) Phase II Study of Erlotinib in Recurrent or Metastatic Endometrial Cancer: NCIC IND-148. Journal of Clinical Oncology, 26, 4319-4325. http://dx.doi.org/10.1200/JCO.2007.15.8808

[95] Leslie, K., Sill, M., Lankes, H., Fischer, E., Godwin, A., Gray, H., et al. (2012) Lapatinib and Potential Prognostic Value of EGFR Mutations in a Gynecologic Oncology Group Phase II Trial of Persistent or Recurrent Endometrial Cancer. Gynecologic Oncology, 127, 345-350. http://dx.doi.org/10.1016/j.ygyno.2012.07.127

[96] Hogberg, T. (2011) What Is the Role of Chemotherapy in Endometrial Cancer? Current Oncology Reports, 13, 433441. http://dx.doi.org/10.1007/s11912-011-0192-X

[97] Konecny, G., Venkatesan, N., Yang, G., Dering, J., Ginther, C., Finn, R., et al. (2008) Activity of Lapatinib a Novel HER2 and EGFR Dual Kinase Inhibitor in Human Endometrial Cancer Cells. British Journal of Cancer, 98, 10761084. http://dx.doi.org/10.1038/sj.bjc.6604278

[98] Vandenput, I., Vanden Bempt, I., Leunen, K., Neven, P., Berteloot, P., Moerman, P., et al. (2009) Limited Clinical Benefit from Trastuzumab in Recurrent Endometrial Cancer: Two Case Reports. Gynecologic and Obstetric Investigation, 67, 46-48. http://dx.doi.org/10.1159/000161568

[99] El-Sahwi, K., Bellone, S., Cocco, E., Cargnelutti, M., Casagrande, F., Bellone, M., et al. (2010) In Vitro Activity of Pertuzumab in Combination with Trastuzumab in Uterine Serous Papillary Adenocarcinoma. British Journal of Cancer, 102, 134-143. http://dx.doi.org/10.1038/sj.bjc.6605448

[100] Androutsopoulos, G. (2012) Current Treatment Options in Patients with Endometrial Cancer. Journal of Community Medicine \& Health Education, 2, e113.

[101] Androutsopoulos, G. and Decavalas, G. (2013) Management of Endometrial Cancer. International Journal of Translation \& Community Medicine, 1, 101.

[102] Elsahwi, K. and Santin, A. (2011) ErbB2 Overexpression in Uterine Serous Cancer: A Molecular Target for Trastuzumab Therapy. Obstetrics and Gynecology International, 2011, Article ID: 128295.

[103] Fader, A., Santin, A. and Gehrig, P. (2013) Early Stage Uterine Serous Carcinoma: Management Updates and Genomic Advances. Gynecologic Oncology, 129, 244-250. http://dx.doi.org/10.1016/j.ygyno.2013.01.004

[104] Gadducci, A., Tana, R., Cosio, S., Fanucchi, A. and Genazzani, A. (2008) Molecular Target Therapies in Endometrial Cancer: From the Basic Research to the Clinic. Gynecological Endocrinology, 24, 239-249. http://dx.doi.org/10.1080/09513590801953556 